\title{
Research on Issues Concerning Chinese Civil Servant Resignation Administration
}

\author{
Li Yongkang* \\ School of Public Management, \\ Yunnan University of Finance and \\ Economics \\ Kunming, P.R.China, 650221 \\ Email: 121651831@qq.com
}

\author{
Xie Hejun \\ School of Public Management, \\ Yunnan University \\ Kunming, P.R.China, 650504 \\ Email: hejunxie@yahoo.com.cn
}

\author{
Duan Yuping \\ School of Public Management, \\ Yunnan University of Finance and \\ Economics \\ Kunming, P.R.China, 650221 \\ Email: 379993769@qq.com
}

\begin{abstract}
The resignation system of Chinese civil servants has been basically established, and civil servants have an unimpeded "exit". However, there are several issues in need of in-depth study: firstly there are three issues concerning civil servant resignation administration: adverse selection and brain drain in resignation; singular career choice after resignation; the potential corruption in resignation. Secondly there are three issues in administration over resignation of current jobs: the conflicts between resignation due to job demands and term of office, comeback mechanism arrangement of resigned officials due to accountability; the conflict between ordered resignation and "resignation" rights. Thirdly the resignation administration law is to be completed.
\end{abstract}

Key words - Chinese civil servant resignation administration; Adverse selection; Potential corruption; Comeback confusion

\section{I.INTRODUCTION}

The civil servant resignation system is an important component in civil servant administration, an important part in civil servant system building, and it is related to how to organize civil servant "exit" and party and government leaders "demotion" steps, and also rights guarantee of civil servants and responsible government building. It is of practical significance to further complete the civil servant resignation system, because it is necessary to further complete the civil servant system and it also means actual requirements to realize cadre and human resources system reform objectives and build service-oriented governments. Meanwhile, it is of important theoretical value, and in favor of exploring the theoretical system of Chinese civil servant resignation, and promoting development of public human resources management theories and enrich high-rank official accountability system and responsible government theories.

Although the educational circle holds some different viewpoints about the resignation system, but the "Chinese Civil Servant Law" in force has definitely stipulated that civil servants have the right to "apply for resignation" (Sub-clause 7 of Clause 13), i.e. all civil servants have rights to apply for resignation. Article 82 of "Civil Servant Law" stipulates four ways for party and government leaders and cadres to quit: resignation due to work change, voluntary resignation, blame-taking resignation and ordered resignation. As a result, Chinese civil servant resignation system has been shaped basically, and the content and system is comprised of civil servant resignation (Hereinafter referred to as "resignation from public service") and party and government leader and cadre resignation (Hereinafter referred to as "resignation from current positions"). Resignation from public service includes all behaviors for all civil servants to resign from public services, including that of ordinary civil servants and also leaders and cadres; the reasons for resignation include four types: resignation due to work change, voluntary resignation, blame-taking resignation and ordered resignation. Blame-taking resignation and ordered resignation are two ways to implement accountability to party and government leaders and cadres.

Two supporting laws and regulations concerning administration over civil servants are promulgated based on "Civil Servant Law". One is "Temporary Regulations concerning Resignation of Party and Government Leaders and Cadres" in 2004, which is formulated and executed by the Organization Department of the Central Committee of the CPC in accordance with the principle of "placing cadres under party supervision", and it is the specific management regulation concerning resignation of party and government leaders from present positions; the other is "Stipulations concerning Resignation of Civil Servants from Public Service (Trial)" in 2009. The stipulations are jointly formulated and issued by the Organization Department of the Central Committee of the CPC and the Ministry of Human Resources and Social Security, as the specific regulations for organization and human resources departments to administrate resignation of civil servants from public services.

However, since "Civil Servant Law" is implemented, further study on several major theoretical and practical issues concerning administration over resignation of civil servants is needed. The thesis will be focused on analyzing these issues in an attempt to attract academic attention.

\section{II.ISSUES CONCERNING RESIGNATION FROM PUBLIC OFFICE}

\section{A.Adverse Selection and Brain Drain in Resignation}

Adverse selection: some scholar thinks in the downsizing of public sectors, "generally speaking, the government drives civil servants to voluntarily resign or retire in advance only by financial incentives, such as providing severance pay or compensation, or assigning new positions or careers (Possibly not civil servants) for staffs, so that they will leave positions to be removed"; "the goal of downsizing is to dissolve redundant personnel and keep elites". [1] However, the practical downsizing tells another story in which redundant personnel, in fear of losing the identity of civil servants, refuse to leave if there are no good positions for them, and on the contrary, they 
will exclude elites necessary out of the civil servant team, so elites are lost and adverse selection emerge, in which qualified ones leave and disqualified ones stay. [2]

One of the functions of civil servant resignation system design is to have impeded civil servant exits, and promote free flow of talents between public sectors and all social industries. However, the adverse selection in reality leads to brain drain of government sectors. The statistical result from spot check of the Ministry of Human Resources and Social Security to 21 central ministries and commissions reveals that in four years from 1998 to 2002, altogether 1,039 civil servants of regular college graduates or above in these 21 units resigned (quit), accounting for $8.8 \%$ of total civil servants of the same education background. A lot of personnel of education background concerning foreign affairs, such as foreign languages, international laws, international economy, international trade, international finance, and auditing concerning foreign affairs resigned. In the respect of ministries and commissions, 164 civil servants from the Ministry of Foreign Affairs quit, including 136 involving diplomatic businesses, accounting for $83 \%$; 13 from 22 resigned people in the Ministry of Culture were foreign language majors, making up of $59 \%$. Accordingly relevant ministries and commissions of these majors suffer severe brain drain. For example, 158 from the original Ministry of Foreign Trade and Economic Cooperation, 157 from the Ministry of Foreign Affairs, 107 from People's Bank of China, and 88 from the Audit Office quit. Among the resigned, most are young civil servants. For example, $80 \%$ resigned people from the Ministry of Foreign Affairs are below 35 years' old; 123 young civil servants in the original Ministry of Foreign Trade and Economic Cooperation from 1999 to 2001 quit, which were $72.8 \%$ of total college graduates recruited during that period. [3] According to the survey on Guangdong, altogether 2,081 civil servants gave up public services in Guangdong Province from 1994 to 2003, accounting for $1.7 \%$ of total civil servants. [4] During recent years, a growing number of officials of ministries and commissions give up all positions, transfer to "business activities", and seek employments in subordinate holding agencies or supervised institutions. Anti-tax avoidance experts of the taxation system end up to be tax risk partners of the

international accounting firm. [5] Officials of China Securities Regulatory Commission are employed in securities \& stock companies. According to prospectus placement published by the fund company, nearly 50 civil servants concerning securities regulation quit their jobs and hold top management positions in fund companies. At present these people are working in over 30 fund companies at home. [6] On the other hand, a growing number of civil servants quit, so to some extent the exit problem of civil servants is alleviated, making room for fresh hands and young civil servants. On the other hand, some experienced civil servants of certain levels and good education backgrounds flow out of governmental sectors.

\section{B.Singular Career Choice after Resignation}

By analyzing civil servant resignation of over 30 years from reform and opening up, most of the resigned go to foreign enterprises, private enterprises and state-owned enterprises; and few choose education, public good, etc. Most transfer to "do business", so that resigning of civil servants is deemed as doing business to the public. According to statistics of relevant departments of Zhejiang Province, 125 party and government cadres of above county (department) levels in the whole province (sectors directly under the administration of the province and 11 cities) from 2000 to March 2003 resigned or retired in advance, including 22 from sectors directly under the administration of the province, 103 municipal and county level officials, and 9 department level officials. 77 out of 125 resigned officials go to private enterprises, i.e. $62 \%$. 46 management personnel from Zhejiang Guangsha Holding Co., Ltd. once were cadres of department levels. [7] As shown in table 1, one survey on national talent flow shows most talents choose foreign enterprises, i.e. close to $41 \%$; if the quantity of resigned people going to private and listed companies is added the proportion will be $68 \%$; only less than $13 \%$ of the resigned would like to go back to be civil servants again. [8] This indicates that the proportion of civil servants is basically consistent with that proportion of nationwide talents flowing to enterprises, and most of them choose to work in enterprises. The flowing direction of resigned civil servants is comparatively singular and in need of policy guidance strengthened by the state.

Table 1 Choice Relations of Chinese AREas and TAlent Flow Organizations

\begin{tabular}{|l|l|c|c|c|c|c|c|}
\hline \multicolumn{1}{|c|}{ Location } & $\begin{array}{c}\text { State-owne } \\
\text { d enterprise }\end{array}$ & $\begin{array}{c}\text { Private } \\
\text { enterprise }\end{array}$ & $\begin{array}{c}\text { Foreign } \\
\text { enterprise }\end{array}$ & $\begin{array}{c}\text { Listed } \\
\text { company }\end{array}$ & $\begin{array}{c}\text { Public } \\
\text { institutions }\end{array}$ & $\begin{array}{c}\text { Government } \\
\text { al sectors }\end{array}$ & Others \\
\hline Northeast China & 13.7931 & 10.34483 & 37.93103 & 27.58621 & 6.896552 & 6.896552 & 10.34483 \\
\hline North China & 2.564103 & 12.82051 & 41.02564 & 10.25641 & 17.94872 & 12.82051 & 2.564103 \\
\hline East China & 2.5 & 12.5 & 45 & 25 & 15 & 12.82051 & 0 \\
\hline South China & 5.555556 & 14.58333 & 40.97222 & 10.41667 & 15.97222 & 10 & 7.638889 \\
\hline Middle China & 3.076923 & 10.76923 & 35.38462 & 13.84615 & 16.92308 & 11.80556 & 6.153846 \\
\hline Northwest China & 0 & 3.703704 & 48.14815 & 18.51852 & 7.407407 & 14.81481 & 7.407407 \\
\hline Southwest China & 5.555556 & 5.555556 & 38.88889 & 22.22222 & 13.88889 & 11.11111 & 2.777778 \\
\hline Total & 4.358354 & 11.86441 & 40.9201 & 15.49637 & 15.01211 & 12.83293 & 5.326877 \\
\hline
\end{tabular}

(Data source: Wu Bo, Current Talent Flow in China, September 2005, Page 158)

\section{Potential Corruption in Resignation}

1)Go into Business to Make Fortune and Retain the Job for Retirement
"Going into business with payments" and "retaining the job but suspending the salary" are ways to complete institutional reform tasks to some extent, and some people are "invisible" in workplaces to complete the downsizing objectives. When the institutional reform is no longer a major task and gets no 
attention, most people going into business will go back to the original units for retirement. Based on survey on Yunnan Province, civil servants of provincial departments and sectors who went to do business before have returned to their positions, waiting for retirement. The inextricably tie between civil servants and original units easily triggers collusion between government and businessman and domination over the market, thus destroying the fair play on the market. At present the reason why private enterprises like officials is mostly because they give attention to officials' connections and information resources.

\section{2)Afraid of Not Officials' Resignation and but Collusion} between Government and Businessmen

It has had negative impact on the masses that a few leaders and cadres resign to go into business or seek for profits by utilizing original powers and rights during recent years. Targeting at this, netizens think some restrictions on retired or resigned civil servants who do business may better protect national security and reduce and contain corruption. A review from people.com.cn says business operation of resigned officials is easily involved in the scope of original powers and administration and relevant work areas. In order to seek for profits and avoid punishment, some people give favors for some people and some industrial areas, so that they may get rewards after resignation. This is "option corruption" criticized by the society. Once "option" is certain, some people will take initiative to resign and "cash" the option. However, according to opposite opinions, resignation and business operation of civil servants could promote employment. Not all resignation and business operation of civil servants will result in corruption, and this cannot be totally repudiated. ${ }^{[9]}$

In fact, frequent issues are partial and complete collusion of government and businessman. For example, retired cadres are employed as part-time directors in enterprises; the cadres returning to units do business with partners secretly or do "business of governmental background", etc. The statistics about officials' employment in listed private enterprises indicates that the position former officials hold the most in listed private enterprises is independent director, involving 139 people, followed by director held by 74 people and supervisor held by 43 . These three positions are completely nominal posts, and $76.6 \%$ are held by officials. ${ }^{[10]}$ It therefore is hard for the society to believe that the motivation for private enterprises to employ officials to work in their companies and for officials to go into business is pure. Relevant administrative authority should investigate and clarify the circumstances pursuant to laws.

\section{3) Guard against Resignation and absconding of "Naked} Officials"

The phrase "naked official" was invented by Chinese netizens in 2008, and it refers to civil servants whose spouse and children live out of the territory, and acquire foreign nationality or foreign permanent residency permits. According to the information disclosed by the Organization Department of the Central Committee of the CPC in 2010 indicates that spouses and children of 1.18 million officials (civil servants and leaders and cadres of state-owned enterprises and public institutions) settle down abroad, that's to say, nearly 40,000 "naked official" in every province on average, and over 50 "naked officials" in every county and city. [11] On the other hand, the incidents about "naked officials" turning into corrupted officials and ending up as "fleeing officials" are shocking. It is reported that altogether over 16,000 fleeing officials from provincial, ministerial to deputy department levels embezzled and took away over RMB 1 trillion overseas from 1992 to June 2007. These fleeing greedy officials are almost all "naked officials" [12]. Targeting at this phenomenon, the party and government have gradually promulgated relevant policies and stipulations to strengthen administration. On February 22, 2010, "2010 Work Focus of State Bureau of Corruption Prevention" published by the Ministry of Supervision, and supervision over naked officials was brought up for the first time as the work focus of the State Bureau of Corruption Prevention. On April 23, 2010, CPC Central Committee Political Bureau deliberated "Stipulations concerning Leaders Reporting Relevant Personal Matters and Temporary Stipulations concerning Strengthening Administration over National Staff with Spouses and Children Emigrating to Foreign Countries". In 2011, China carried out registration and administration over "naked officials". Among resignation of civil servants, resignation of "naked officials" is particularly stressed on, registration is carried out according to relevant policies, resignation audit is added, the resignation of "naked officials" having suspected issues will not be approved, and registration and investigation will be conducted.

\section{PROBLEMS IN ADMINISTRATION OVER RESIGNATION FROM CURRENT POSITIONS}

\section{A.The Conflicts between Resignation Due to Job Demands and Term of Office}

Resignation due to job demands means position changes of leaders during their terms of office, and if not well handled, it will have conflicts with the leaders' tenure system. Article 3 of "Temporary Regulations concerning Tenure of Party and Government Leaders and Cadres" stipulates that every term of office of party and government leaders and cadre is five years. Article 4 stipulates that Party and government leaders and cadre should be kept steady during the tenure. One of the conditions to make adjustment within the tenure is that "positions should be adjusted due to special work requirements". This means that position's tenure system is the foundation, and the change of position is the adjustment according to actual work requirements, which is conditional and individual. Resignation due to job should be prevented in a few places, which is caused by sudden promotion and violates the tenure system.

\section{B Comeback Arrangement of Resigned Officials Due to Accountability}

\section{1) Confused Time Limits for Comeback}

"Work Regulations concerning Selecting and Appointing Party and Government Leaders and Cadres" in 2002 stipulates "cadres that resign to assume responsibilities, resign by 
following orders or get demotion, may be appointed or selected to hold positions as leaders if they work in the new positions for longer than one year, have outstanding performance and meet selection and appointment conditions." The time limit to be appointed or selected as leaders again is "longer than one year". Article 10 of "Temporary Stipulations concerning Implementing Accountability of Party and Government Leading Cadres" in 2009 stipulates that "cadres that resign to assume responsibilities, resign by following orders or get dismissed may not assume positions as leaders equivalent to the original positions. If leader's position equivalent to the original position is held one year later, exam \& approval formalities in accordance with cadre administration authority should be performed, and moreover, opinions of the upper level party and committee organization departments should be solicited." Article 16 of "Accountability Methods for Selection and Appointment of
Party and Government Leaders (Trial)" in 2010 stipulates that "officials that resign to assume responsibilities or by following orders, or get dismissed cannot assume positions equivalent to the original ones, or get promoted within two years". There is difference concerning the time limits for the comeback of leaders who resign to assume responsibilities or by following orders in party stipulations published in three different years. Seen from the party stipulation formulation time, the stipulations in 2010 is obviously more practical. However, seen from the effectiveness of the party stipulations, evidentially the work regulations in 2002 are superior regulations. This will cause confusion and chaos in administration practice. It can be seen from table 2 that the shortest and longest intervals for comeback of party and government leaders after accountability are 4 months and 15 months respectively.

TABLE 2 INFORMATION ABOUT COMEBACK OF PARTY AND GOVENRMENT LEADERS AFTER RESIGNATION

\begin{tabular}{|c|c|c|c|c|c|}
\hline $\begin{array}{l}\text { Resigned } \\
\text { cadre }\end{array}$ & $\begin{array}{ll}\text { Position } & \text { before } \\
\text { resigantion } & \end{array}$ & $\begin{array}{l}\text { Resigntion } \\
\text { time }\end{array}$ & Position after comeback & $\begin{array}{l}\text { Comeback } \\
\text { time }\end{array}$ & $\begin{array}{l}\text { Comeback } \\
\text { interval }\end{array}$ \\
\hline $\begin{array}{l}\text { Meng } \\
\text { Xuenong }\end{array}$ & $\begin{array}{l}\text { Mayor of Beijing } \\
\text { City }\end{array}$ & March 2003 & $\begin{array}{l}\text { Deputy Director of General Office } \\
\text { of South-North Water Transfer } \\
\text { Project Construction Comitee of } \\
\text { the State Council }\end{array}$ & $\begin{array}{l}\text { September } \\
2003\end{array}$ & $\begin{array}{l}\text { Six } \\
\text { months }\end{array}$ \\
\hline $\begin{array}{l}\text { Zhang } \\
\text { Wenkang }\end{array}$ & $\begin{array}{l}\text { Minister of the } \\
\text { Ministry of Public } \\
\text { Health }\end{array}$ & April 2003 & $\begin{array}{l}\text { Deputy Director of Song Chiing } \\
\text { Ling Foundation, Deputy Director } \\
\text { of Science, Literature and Art and } \\
\text { Sports Commitee }\end{array}$ & $\begin{array}{l}\text { October } \\
2003\end{array}$ & $\begin{array}{l}\text { Six } \\
\text { months }\end{array}$ \\
\hline Ma Fucai & CEO of PetroChina & $\begin{array}{l}\text { December } \\
2003\end{array}$ & $\begin{array}{l}\text { Deputy Director of National } \\
\text { Energy Office }\end{array}$ & May 2005 & 13 months \\
\hline $\begin{array}{l}\text { Xie } \\
\text { Zhenhua }\end{array}$ & $\begin{array}{l}\text { Director General of } \\
\text { Sate Environmental } \\
\text { Portection } \\
\text { Administration }\end{array}$ & $\begin{array}{l}\text { December } \\
2005\end{array}$ & $\begin{array}{l}\text { Party member and Deputy Director } \\
\text { of National Development and } \\
\text { Reform Comission }\end{array}$ & $\begin{array}{l}\text { December } \\
2006\end{array}$ & 1 year \\
\hline $\begin{array}{l}\mathrm{Li} \\
\text { Changjiang }\end{array}$ & $\begin{array}{l}\text { Director General of } \\
\text { General } \\
\text { Administration of } \\
\text { Quality Supervision, } \\
\text { Inspection and } \\
\text { Quarantine }\end{array}$ & $\begin{array}{l}\text { September } \\
2008\end{array}$ & $\begin{array}{l}\text { Full-Time Deputy Team Leader of } \\
\text { National "Fight against } \\
\text { Porngraphy and Illegal } \\
\text { Publications" Work Team }\end{array}$ & $\begin{array}{l}\text { December } \\
2009\end{array}$ & 15 months \\
\hline $\begin{array}{l}\text { Meng } \\
\text { Xuenong }\end{array}$ & $\begin{array}{l}\text { Provincial Governor } \\
\text { of Shanxi Province }\end{array}$ & $\begin{array}{l}\text { September } \\
2008\end{array}$ & $\begin{array}{l}\text { Deputy Secretary of Work } \\
\text { Committee of Agencies Directly } \\
\text { under CCCPC }\end{array}$ & $\begin{array}{l}\text { January } \\
2009\end{array}$ & 4 months \\
\hline
\end{tabular}

2) Insufficient Basis for Comeback

"Accountability Methods for Selection and Appointment of Party and Government Leaders (Trial)", printed and distributed by the General Office of the CPC Central Committee in March 2010, stipulates that "it is required to comprehensively consider track records, qualifications, strong points, etc. of party and government leaders who resign to assume responsibilities and by following orders, get dismissed or demoted, reasonably allocate work posts and corresponding work tasks, and meanwhile decide corresponding positions and benefit packages." However, this doesn't mean appointing leadership positions, and moreover, how can we define the scope of "comprehensive consideration"? What is the standard on earth of "comprehensive consideration"? These answers to the doubts are unknown to the public.

3)Absence of Public Supervision during Comeback 
The "comeback" course of most officials is not transparent and invisible, so the public's rights to know and supervise are ignored. On December 24-25, 2009, the public learnt from the news that Li Changjiang, Full-Time Deputy Team Leader of National "Fight against Pornography and Illegal Publications" Work Team Went to Jiangsu for Investigation" Li Changjiang, the previous Director General of General Administration of Quality Supervision, Inspection and Quarantine, who resigned to assume responsibilities due to "Sanlu" incident, had a "comeback", and he sparked heated public discussions. "The public should not be the last one to know the comeback of Li Changjiang", according to the comment of some media ${ }^{[13]}$. Before NPC \& CPPCC in 2013, Zhou Bohua, Director General of National Administration of Industry and Commerce, almost shed tears when saying "people of Mainland China have no confidence in the quality of milk powder". Although the lingering impact of poisonous powered milk incidents a few years ago is so huge, several resigned officials involved have come back successively without letting the public know. They can go back to work and inferior quality powered milk is seen on the shelf again, so there is no wonder that there is no way for the public to believe in the quality of powdered milk produced at home. If the comeback course of the resigned officials fails to be supervised by the masses and transparent operation is impossible, stipulations of "promotion within two years" will be a dead letter, and it's hard for the public to believe the basis for the comeback of these officials.

\section{The Conflict between Ordered Resignation and "Resignation" Rights}

Pursuant to stipulations of international practice and "Civil Servant Act", it is generally agreed that the resignation of civil servants is a "right". However, "ordered resignation" of party and government leaders and cadres, as one type of "resignation", is "ordered". High-rank officials in western countries may be forced to resign, and some official may leave his position under the pressure of public opinions. However, it's up to the official to decide to resign or not. If the official is passively blamed, the official involved will be impeached or dismissed from his post. As one of the ways to blame party and government leaders and cadres, the "ordered resignation" in China is feasible, and it is between "resignation to assume responsibility" and "dismissal". However, as a resignation way, "ordered resignation" is obviously not the active behavior of party and government cadres, and it has conflicts with Sub-clause 7 of article 13 in "Civil Servant Law" , "civil servants have the right to apply for resignation", resulting in inconsistency in a law.

\section{THE RESIGNATION ADMINISTRATION LAW IS TO BE COMPLETED}

\section{A "Resignation and Dismissal" Combined into One Chapter to be Discussed}

Both "Provisional Regulations concerning National Civil Servants" in 1993 and "Civil Servant Law" in 2005 have one particular chapter to regulate "resignation and dismissal" administration over civil servants. Although resignation and dismissal have overlaps in some parts of administration, the difference of the two is comparatively obvious. Moreover, the resignation system includes the resignation of party and government cadres, so the mix of the two in laws and regulations leads to confusion in actual practice. The problem is already partially corrected. In 2009, the Organization Department of the Central Committee of the CPC and the Ministry of Human Resources and Social Security printed and distributed "Stipulations concerning Resignation of Civil Servants from Public Service (Trial)"and "Regulations concerning Resignation of Civil Servants (Trial)" in 2009 respectively. These two supporting laws stipulate clear separation of dismissal and resignation, which is in favor of combining resignation of civil servants and resignation from present positions of party and government cadres, thus forming the complete civil servant resignation system and legal system. For this reason, NPC is recommended to separate "resignation" from "dismissal" when amending partial articles of "Civil Servant Law", in an attempt to further complete civil servant resignation system.

\section{B. Ambiguity of Audit during Resignation}

Article 24 of "Temporary Regulations concerning Resignation of Party and Government Leaders and Cadres" in 2004 clearly stipulates that "if economic responsibility auditing is necessary according to relevant stipulations when party and government leaders and cadres resign, party committee (leading party groups) and the organization (human resources) department should entrust audit authority for economic responsibility auditing." Article 86 of the "Civil Servant Law" in 2005 also stipulates that "when civil servants resign or get dismissed, they should handle official business takeover formalities before resignation, and accept auditing pursuant to stipulations when necessary". Article 7 of "Stipulations concerning Resignation of Civil Servants from Public Service (Trial)" in 2009 once again stipulates that "civil servants approved of resignation should handle takeover formalities before resignation and accept auditing pursuant to stipulations when necessary". Three stipulations all clearly stipulate that resigned civil servants should accept resignation audit. However, ambiguous words like "pursuant to relevant regulations" "when necessary" means resignation audit is nominal or just goes through the motions, and relatively much discretion and arbitrariness exist.

\section{Endowment Insurance of Voluntary Resignation of Civil Servants}

One major barrier for civil servants to resign from public services is that civil servants' endowment insurance system is not supported. If the civil servant takes the initiative to resign before retirement, the benefits after retirement may be not secured. Therefore, some civil servants just get through the day, lack work passion, have the idea of resignation, but don't take actions. In 2005, a civil servant, quitting the 21-year job, is employed in an enterprise. He is refused by the Bureau of Finance for the lump sum endowment insurance, and the reason is that civil servants transferred to enterprises from government sectors may get a lump sum basic endowment insurance compensation, but resigned ones who are employed by enterprises are an exception. ${ }^{[15]}$ 
This is quite controversial. A few places carry out pilot programs. For example, "Reply to Endowment Insurance concerning Resigned or Dismissed Civil Servants" (M.R.S.H. [2009] No. 288) of Fujian Province Social Security Bureau stipulates that "After civil servants find employment after resignation or dismissal and get involved in enterprises' employees' basic endowment insurances, the consecutive working years in the original work unit before resignation or dismissal may be deemed as fee payment years, and combined with the actual payment years." Most places comply with "Provisional Methods concerning Basic Endowment Insurance Transfer and Renewing of Urban Enterprise Employees" of the Ministry of Human Resources and Social Security and the Ministry of Finance. The methods are applicable for all people involved in basic endowment insurances of urban employees. However, nothing is mentioned for endowment insurance for career flow, for example, resigned civil servants flowing to enterprises or enterprise employees flowing to be civil servants. ${ }^{[16]}$ In 2015 the Ministry of Human Resources and Social Security started to connect endowment insurance of civil servants staff in public institutions and enterprise employees, but the former two also need to deduct endowment insurance fee from their salary, and receive endowment pension from the social security bureau like enterprise employees. However, the problem of endowment insurance calculation, transferring and renewing of resigned civil servants remains unresolved institutionally.

\section{SUMMARY}

The issues above need the attention of theoretical cycle and practice departments. Only based on increasing study, Chinese civil servant resignation system and administration practice may be completed, and meanwhile, civil servant system and theories about human resources management of public sectors may be improved, and civil servant administration will be promoted to be increasingly scientific and standard.

\section{ACKNOWLEDGEMENT}

The study is funded by Chinese national social sciences fund "Empirical Study on Resignation Behaviors of Civil Servants" (Grant No.: 14BZZ055) and "Study on Issues of Civil Servant Resignation and Countermeasures-Take Yunnan Province for Example" in "Talent Introduction" Program of Yunnan University of Finance and Economy.

\section{REFERENCES}

[1] Wu Qiongen, Zhang Shijie, Xu Shiyu, Dong Keyong, Cai Xiujuan, Su Weiye, "Public Human Resources Management, " Beijing: Peking University Press, 2006, pp. 351-352. (In Chinese)

[2] Wang Hu, "Civil Servants Drain Report: Brain Drain of 1,039 People in Central Ministries and Commissions within Three Years , "21st Century Economic Report, 2003-09-10. (In Chinese)

[3] Luo Liqian, Survey on Resignation, Discharge and Dismissal of Civil Servants of Guangdong Province . Academic Search for Truth and Reality, 2006(5). (In Chinese)
[4] Wang Chao, "Huge Tax Erosion Caused by Tax Avoidance , " China Youth Daily, 2012-05-02.

[5] Going into Business of Officials of China Securities Regulatory Commission, How to Put Out and Prevent Fire. Southern Weekly, 2012-10-19.

[6] Zhou Qinghang, Wu Xinzhong, “Analysis of Business Operating of the New Round of Officials , "Party \& Government Forum, 2005(2).

[7] Wu Bo, “ Contemporary Chinese Talent Flow , ” Beijing: People's Publishing House, 2005, pp. 158.

[8] "Restrictions on Business Operation, " Career, 2009(11). (In Chinese)

[9] "Officials of Listed Companies, " Investor Journal, 2010-07-05. (In Chinese)

[10] Li Xiujiang, “Converging Attack of Naked Officials , "Well-off, 2010(9). (In Chinese)

[11] Jiang Suoliang, "Moral Analysis of Naked Officials and Prevention ,"Journal of China National School of Administration, 2011(6). (In Chinese)

[12] "Comeback of Li Changjiang, the Public should not be the Last to Know ,’Yanzhao Evening News, 2009-12-28. (In Chinese)

[13] "Director General of the State Administration of Industry and Commerce Wants to Shed Tears for Citizens' no Confidence in Milk Powder Safety," http://politics.people.com.cn/n/ 2013/0303/c70731-20656772.html. (In Chinese)

[14] Jiang Guibin, "Session Opening of Retired Civil Servants' Endowment Insurance," Beijing Morning Post, 2005-10-25. (In Chinese)

[15] Du Wenge, "Solution of Endowment Insurance of Retired Civil Servants Good for Downsizing," Demoracy and Legal System Times, 2010-01-25. (In Chinese) 